\title{
The Effect of Compensation and Job Satisfaction on the Teacher Work Motivation on Islamic Junior High School 2 Oku Timur
}

\author{
Aida Fitri ${ }^{1 *}$, Bukman Lian ${ }^{1}$, Alhadi Yan Putra ${ }^{1}$ \\ ${ }^{1}$ Universitas PGRI Palembang, Indonesia \\ *Corresponding author. Email: aidafitri271172@gmail.com
}

\begin{abstract}
The work motivation of the teachers at Islamic Junior High School 2 OKU Timur is still lacking, this can be seen from the level of work results that are still late or experience errors. There is an influence between job satisfaction on the work motivation of teachers at Islamic Junior High School 2 OKU Timur. There is an influence between compensation and job satisfaction together on the work motivation of teachers at Islamic Junior High School 2 OKU Timur. The researcher collects the data by using observation, interviews and questionnaires. The analysis carried out was the correlation analysis of the $\mathrm{t}$ test and the $\mathrm{F}$ test. The results of the data analysis from the questionnaire showed that the results of the t-test were 11,257 with a sig 0,000 level, so the hypothesis was concluded that: 1) there was an effect of compensation on the work motivation of the teachers in Islamic Junior High School 2 OKU Timur of 74.9\%; 2) there is an effect of Job Satisfaction on the work motivation of teachers at Islamic Junior High School 2 OKU Timur of 76.4\%, and 3) there is an effect of Compensation and Job Satisfaction collectively on the work motivation of Islamic Junior High School 2 OKU Timur teachers by $78.9 \%$.
\end{abstract}

Keywords: Motivation, Compensation and Performance

\section{INTRODUCTION}

Human resource management is very important for organizations in managing, managing and utilizing teachers, so that they can function productively to achieve organizational goals, with professional human resource management arrangements, teachers are expected to work productively [1].

One of the factors that is usually a problem with high work motivation for teachers is that teachers will always try to work better at the institution. Work motivation from the teacher is a desire of the teacher to meet their needs, be it the need for a decent life, health and the desire to work well in an organization. For teachers, work motivation is important in order to achieve teacher goals such as meeting needs and careers. Whereas for organizations, work motivation is one of the instruments in achieving organizational goals and the expectations and aspirations for teachers need to be provided by the leadership. At Islamic junior high school 2 OKU Timur, one form of motivation provided by the institution in increasing the work motivation of its teachers is by allowing high-achieving teachers to continue higher education, this is expected that teachers can compete to be the best. In addition, the motivation given is giving bonuses to teachers at work or giving prizes for teachers' services in work such as allowances (Interview with teachers, May 15, 2020).

To get the high and maximum teacher work motivation, Islamic junior high school 2 OKU Timur has made changes and improvements to the existing system, including the provision of high compensation and teacher satisfaction at work. The compensation provided by the institution for teachers is financial and non-financial, in the form of financial compensation in the form of money, family allowances, as well as bonuses for outstanding employees. This provision was carried out by Islamic junior high school 2 OKU Timur so that the teachers were more active in working because the rewards they received could meet the needs of themselves and their families so that no longer were teachers looking for additional income outside or during working hours, while non-financial compensation was in the form of health and safety insurance. family as well as promotion and promotion to a higher level than before. With the existence of appropriate and balanced compensation for the performance shown by the teachers, it is hoped that teachers can improve the quality and efficiency of their resources effectively and efficiently in order to increase the work motivation of teachers at Islamic junior high school 2 OKU Timur (Interview with teachers on 15 May 2020). 
Besides the high compensation given by the institution which is expected to increase the work motivation of teachers, which is not less important, namely the ability of individuals to work. The teachers certainly have different abilities from each other starting from the level of education to the skills they have, for this reason, Islamic junior high school 2 OKU Timur needs to provide guidance to these teachers, especially the problem of teacher satisfaction at work. Facing this problem, Islamic junior high school 2 OKU Timur has improved a comfortable working environment, complete facilities and fostering work relations among teachers so that the benefits received are good according to the workload. The high job satisfaction obtained by a teacher at work is expected to be able to build an organization that is better in accordance with organizational goals. Good work motivation from the teachers may increase if the teacher has received satisfaction at work and is supported by high compensation received. Those teachers at Islamic junior high school 2 OKU Timur need attention from the institution, because it is one of the main keys to the achievement of the goals of an institution.

From the description above, the authors are interested in examining the problem of the effect of compensation and training education on teacher work motivation as outlined in the title "The Impact of Compensation and Job Satisfaction on Teachers' Work Motivation at Madrasah Tsanawiyah Negeri 2 OKU Timur, so that motivation is a number of conditions that exist within a person that are used to activate or shape behavior. Then the behavior is directed towards achieving goals and maintaining them until the desired goals are achieved.

Motivation is a process that begins to be carried out by a person due to needs, both psychological needs and physiological needs, so as to drive behavior and generate impetus to achieve a goal. In that case, motivation has three elements which are related to one another [2]. The three elements in question are needs (needs), drives (drives), and stimuli or goals (incentives). These three elements also create a process in a person. Therefore, the main key to understanding the motivation process in individuals actually lies in the meaning and relationship between the three elements above.

Motivation is a state in a person's personality that encourages an individual's desire to carry out certain activities in order to achieve a goal [3].

Compensation is a form of appreciation given by the company to employees in return for services or contributions provided by employees for the progress and achievement of company goals [4]. Factors that affect the amount of compensation received by employees as explained by Khaerul (2001: 56) include paying attention to and paying attention to labor market conditions, regulations set by the government regarding compensation policies, work agreements with employees. The benefits obtained believe that this compensation can improve employee performance in the company, employees will be more enthusiastic in the work offered, work motivation will increase [5].

Two measuring tools or approaches that can be used in providing compensation by companies, namely normative measurement tools and policy measurement tools [6]. Where the compensation provided by this law includes salaries or salaries and fixed components that have been determined by the company since its establishment, benefits received by employees during religious holidays and health benefits for employees and their families. While compensation is political in nature, namely compensation provided by the company on the basis of special considerations, including food allowances received by employees every time they come to work and transport, bonus / incentive allowances, leave and salary.

From the description above, it can be synthesized that compensation is any form of compensation received by a person (teacher) as a return for their efforts, either in the form of direct financial compensation or indirect financial compensation. Direct financial compensation includes salaries, wages, commissions and bonuses that can be received by teachers directly in the form of money, while indirect financial compensation includes allowances, insurance, support costs for education, payments when not working, namely sickness, vacation and so on can be accepted by the teachers indirectly.

That the fulfillment of needs including the lowest level does not lead people to a feeling of satisfaction and leads to a neutral work attitude. This is due to the need for support from other people or from the community. The expression of a pleasant or unpleasant emotional state is a picture of the job satisfaction of the teachers [7].

Job satisfaction is a positive attitude that a person has towards his job. In this respect, the individual loves his job and the work itself suits his needs, so that a person can be pleased with what he is doing on his own. Job satisfaction is a feeling of pleasure or displeasure with someone's job and this can be influenced by the environment. Job satisfaction is very much determined by work and work environment conditions can meet work needs [8]. This means that environmental conditions greatly affect a person's satisfaction with the work he is doing, a good environment will certainly add to a person's enthusiasm for work because there he can think well and calmly. This is very different if the environment in the workplace that does not support smooth work, for example the place, cleanliness and so on, will certainly hinder the progress of members to think and work well.

This opinion was also expressed who say job satisfaction reflects a person's feelings about their work and everything they face in the work environment [9] 
Based on the description of the theoretical theory above, it can be concluded that job satisfaction is a positive or happy feeling from someone towards their work which is oriented towards the results of their work so far. The indicators of job satisfaction above are: the nature of the job itself, the work environment, pay and rewards, and the work achieved.

\section{METHODS}

The place for the research was in Islamic junior high school 2 OKU Timur.

In this study, the authors used quantitative data, namely research that is required to use numbers, starting from data collection, interpretation of data, and the appearance of the results. Quantitative research is a type of research whose specifications are systematic, planned, and clearly structured from the start to the making of the research design.

Population is "a generalization area consisting of objects or subjects that have certain quantities and characteristics that are expected by researchers to study and then draw conclusions" [10]. The population that became the object of this study were all teachers at
Islamic junior high school 2 OKU Timur, totaling 54 teachers.

The sample is part or representative of the population under study. To determine the size of the sample if the subject is less than 100, it is better to take all of them so that the research is population research. If the subject is bigger it can be taken between $20-25 \%$ [11].

In this study, all of the population were taken as the research sample, namely 54 people, while 20 people were used to try out research instruments. The 20 people were taken from other schools, namely Islamic junior high school 2 OKU Timur.

In this study the authors used quantitative data, namely research that is required to use numbers, starting from data collection, interpretation of the data, and the appearance of the results. To collect research data, the authors used observational methods, questionnaires and documentation.

\section{RESULTS AND DISCUSSION}

1) Compensation Hypothesis Testing $\left(X_{1}\right)$ on Work Motivation (Y)

\begin{tabular}{|c|c|c|c|c|c|c|}
\hline & & Table & Test $\mathbf{R}$ & lits $X_{1}$ Against & & \\
\hline & del & Unstanc & dized & Standardized & $\mathrm{t}$ & Sig. \\
\hline & & $\mathrm{B}$ & $\begin{array}{l}\text { Std. } \\
\text { Error }\end{array}$ & Beta & & \\
\hline 1 & (Constant) & -11.171 & 6.184 & & -1.806 & 0.001 \\
\hline & Compensation & 0.949 & 0.076 & 0.866 & 12.462 & 0.000 \\
\hline
\end{tabular}

From the table above, the $t$ value is 12,462 with a sig 0,000 level. Because the sig value is less than 0.05 , the hypothesis which says there is an effect of compensation on teacher work motivation at Islamic junior high school 2 OKU Timur is accepted. This means that compensation affects the motivation to work of teachers at Islamic junior high school 2 OKU Timur.

\section{Hypothesis Testing Job Satisfaction $\left(\mathbf{X}_{2}\right)$ on Work Motivation (Y)}

Table 2. $\mathrm{X}_{2}$ Test Results Against $\mathrm{Y}$

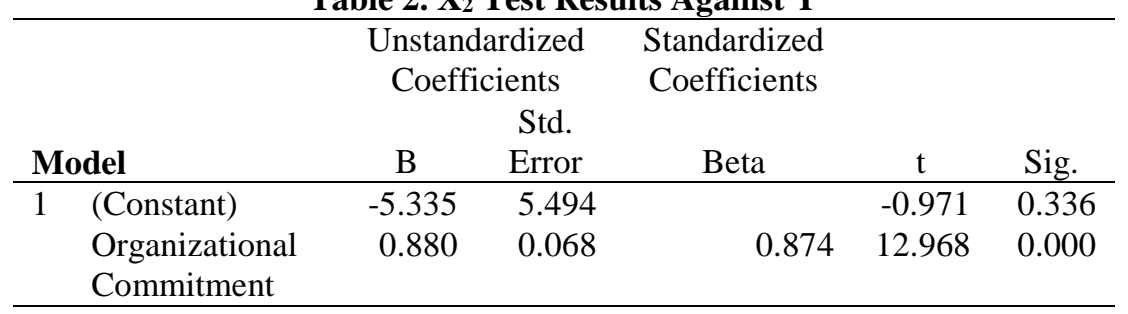

a. Dependent Variable: Work Motivation

From the table above, the t value is 12,968 with a sig 0,000 level. Because the sig value is less than 0.05 , the hypothesis which says there is an effect of Job Satisfaction on Teacher Work Motivation at Islamic junior high school 2 OKU Timur is accepted. This means that Job Satisfaction has an effect on the motivation to work of teachers at Islamic junior high school 2 OKU Timur.667 
3) Compensation Hypothesis Testing $\left(\mathrm{X}_{1}\right)$ and Job Satisfaction $\left(\mathrm{X}_{2}\right)$ on Motivation (Y)

Table 3. Compensation Hypothesis Testing (X1) and Job Satisfaction (X2) on Motivation (Y)

\begin{tabular}{|c|c|c|c|c|c|}
\hline Model & $\begin{array}{l}\text { Sum of } \\
\text { Squares }\end{array}$ & df & $\begin{array}{c}\text { Mean } \\
\text { Square }\end{array}$ & $\mathrm{F}$ & Sig. \\
\hline 1 Regression & 1988.505 & 2 & 994.253 & 95.404 & $.000^{\mathrm{b}}$ \\
\hline Residual & 531.495 & 51 & 10.421 & & \\
\hline Total & 2520.000 & 53 & & & \\
\hline
\end{tabular}

a. Dependent Variable: Work Motivation

b. Predictors: (Constant), Job Satisfaction, Compensation

From the table above, the $\mathrm{F}$ value is 95.404 with a sig 0.000. Because the sig value is less than 0.05, the hypothesis which says there is an effect of compensation and job satisfaction on teacher work motivation at at Islamic junior high school 2 OKU Timur is accepted.

\section{CONCLUSION}

Based on the results of research and data analysis that has been carried out descriptively and hypothesis testing, it can be concluded that there is an effect of compensation on teacher work motivation at Islamic junior high school 2 OKU Timur amounting to $74.9 \%$ with a value of $t=12,462$ with sig 0.000 , there is an effect of job satisfaction on work motivation at Islamic junior high school 2 OKU Timur of $76.4 \%$ with a value of $\mathrm{t}=12,968$. With sig 0,000 , there is an effect of Compensation and Job Satisfaction together on the work motivation of teachers at Islamic junior high school 2 OKU Timur of $78.9 \%$ with a value of $F=95.404$. with sig 0.000. From the comparisons together, the effect of the compensation variable has a smaller joint effect on job satisfaction, namely 2.472 versus 3,108 , so the job satisfaction variable needs to be improved.

For researchers to follow up further on the results of this study by developing independent variables that can increase work motivation of Islamic junior high school 2 OKU Timur. This needs to be done because there are still other factors that have an influence on teacher work motivation apart from compensation and job satisfaction because it is only $78.9 \%$ Teacher work motivation is determined by compensation and job satisfaction, meaning $21.1 \%$ is determined by factors outside of compensation and job satisfaction such as compensation, job satisfaction and others.

\section{ACKNOWLEDGMENT}

Our deepest gratitude goes to Chancellor of Palembang PGRI University, Director of the Postgraduate Program of PGRI Palembang University and the Education Management Study Program of PGRI Palembang University, who have supported us in doing this extraordinary thing. This project is funded independently. We also want to thank our Education
Management friends who helped us a lot in a short time frame to complete this project.

\section{REFERENCES}

[1] Handoko, T. H (2018). Manajemen Personalia dan Sumber Daya Manusia [Personnel and Human Resources Management]. Yogyakarta: BPFE.

[2] Luthans, F. (2000). Organizational Behavior. Singapore McGraw-Hill.

[3] Siswoyo. Dkk. (2001). Ilmu Pendidikan [Science Education]. Yogyakarta: UNY Press.

[4] Marwansyah, M. (2016). Supervisi Pendidikan Kontekstual [Supervision of Contextual Education]. Jakarta: Rineka Cipta.

[5] Khaerul. U. (2010). Perilaku Organisasi [Organizational behavior]. Bandung: Pustaka Setia.

[6] Gibson, J. L., Ivancevich, J. M., \& dan Donnely J. H. (2004). Organisasi: Perilaku dan Struktur [Organization: Behavior and Structure]. Jakarta: Erlangga.

[7] Kadarmo, S. U., Suganda N. D., \& Supono. (2001). Koordinasi dan Hubungan Kerja. Bahan Ajar Diklaipim IV [Coordination and Work Relations. Teaching Materials Diklaipim IV]. Jakarta: Lembaga Administrasi Negara.

[8] Soelaiman, S. (2005). Semangat Kerja dan Mutu Kehidupan Kerja [Work Spirit and Quality of Work Life]. Modul Kuliah PPs, MM: UTP.

[9] Wright, P. M., \& Noe, R. A. (2015) Management of Organizations. Chicago: Irwin.

[10] Anoraga, P., \& Suyati, S. (2019). Perilaku Keorganisasian [Organizational Behavior]. Jakarta: Dunia Pustaka Jaya.

[11] Arikunto, S. (2013). Prosedur Penelitian Suatu Pendekatan Praktik. Edisi revisi-VI, Cetakan ke-13 [Research Procedure A Practical Approach. Revised Edition-VI]. Jakarta: PT. Renika Cipta. 